\title{
IMPLEMENTASI KEBIJAKAN PEMBANGUNAN MELALUI DANA DESA
}

\author{
Kristianus Samsul, Ignatius Adiwidjaja \\ Program Studi Administrasi Publik, FISIP, Universitas Tribhuwana Tunggadewi \\ e-mail: kristianussamsu196@gmail.com
}

\begin{abstract}
Abstrak: Undang-undang Nomor 6 Tahun 2014 tentang Desa merupakan sebagai salah satu bentuk kebijakan pembangunan dari pemerintah dalam rangka mempercepat proses pembangunan yang di atur secara teknis dalam Peraturan Menteri Dalam Negeri Nomor 20 Tahun 2018. Jenis penelitian yang digunakan adalah jenis penelitian kualitatif menggunakan teknik pengumpulan data melalui wawancara, observasi, dan dokumentasi. Sedangkan informan dalam penelitian ini adalah Pemerintah Desa, Badan Permusyawaratan Desa dan Masyarakat. pengambilan sampel secara Purposife Sampling. Untuk menguji keabsahan data, peneliti menggunakan teknik triangulasi. Analisis data dilakukan dengan cara reduksi data, penyajian data, dan penarikan kesimpulan. "Implementasi Kebijakan Pembangunan Melalui Dana Desa" di Desa Waturejo, Kecamatan Ngantang, Kabupaten Malang menunjukkan pada kriteria baik. implementasi kebijakan pembangunan diatas sudah bisa memaksimalkan pelayanan pemerintah Desa kepada masyarakat, Namun belum terlalu berpengaruh terhadap taraf hidup masyarakat secara berkeadilan. Dalam implementasi kebijakan pembangunan bidang pemberdayaan masyarakat mengenai pelatihan perangkat Desa dan keterampilan masyarakat terdapat kendala sebagai bagian dari faktor penghambat yakni: Sumber daya manusia, sikap apatis, serta jarang ada kondisi komunikasi dan kordinasi yang sempurna antara stake holder di Desa.
\end{abstract}

Kata Kunci: Implementasi; Kebijakan Pembangunan; Dana Desa

Abstract: Law Number 6 of 2014 concerning Villages is one form of development policy from the government in order to accelerate the development process that is technically set in the Minister of Home Affairs Regulation No. 20 of 2018. The type of research used is the type of qualitative research using data collection techniques. through interviews, observations, and documentation. While the informants in this study are the Village Government, the Village Consultative Body and the Community. Purposife Sampling sampling. To test the validity of the data, researchers used triangulation techniques. Data analysis was performed by data reduction, data presentation, and conclusion drawing. "Implementation of Development Policy Through Village Funds" in Waturejo Village, Ngantang District, Malang Regency shows good criteria. The implementation of the development policy above has been able to maximize the services of the village government to the community, but it has not been too influential on the standard of living of the community in a just manner. In implementing development policies in the field of community empowerment regarding training of village officials and community skills there are obstacles as part of the inhibiting factors namely: human resources, apathy, and rarely have perfect communication and coordination conditions between stake holders in the village.

Keywords: Implementation; Development Policy; Village Fund

\section{PENDAHULUAN}

Kebijakan umumnya di anggap sebagai pedoman untuk bertindak atau saluran untuk berpikir, di mana dalam kebijakan menjelaskan bagaimana cara pencapaian tujuan dengan menentukan petunjuk yang harus di ikuti. Kebijakan ini di rancang untuk menjamin konsistensi tujuan dan untuk menghindari keputusan berwawasan sempit dan berdasarkan kelayakan. Pada 
intinya bahwa kebijakan sebagai rangkaian rencana atau keputusan untuk kemudian di jadikan acuan tindakan yang akan di manifestasikan dalam bentuk program-program terkait persoalan tertentu dalam rangka mencapai tujuan yang di inginkan. Kebijakan pembangunan Desa di Indonesia adalah bentuk kebijakan publik yang memfokuskan pada pebangunan Desa, terutama didaerah terpinggir dan terbelakang. Pembangunan Desa di Indonesia adalah salah satu yang paling banyak perkembangan penting dalam rangka meningkatkan kesejahteraan masyarakat orang karena populasi besar Indonesia tinggal di Desa dan di daerah pinggiran Kota (daerah pinggiran Kota).

Undang-undang Nomor 6 Tahun 2014 tentang Desa merupakan sebagai salah satu bentuk kebijakan pembangunan dari pemerintah dalam rangka mempercepat proses pembangunan yang di atur secara teknis dalam Peraturan Menteri Dalam Negeri Nomor 20 Tahun 2018. Dari kebijakan tersebut di atas maka dapat di ketahui bahwa perhatian pemerintah republik Indonesia terhadap pembangunan Desa sangat tinggi. Maka ini merupakan sebuah tantangan baru bagi pemerintahan Desa sebagai suatu lembaga yang mengurus urusan pemerintahan.

Pasal 1, ayat (2) Undang-Undang Nomor 6 Tahun 2014, tentang Desa menjelaskan, Bahwa pemerintah Desa adalah penyelenggara urusan pemerintahan dan kepentingan masyarakat setempat dalam sistem pemerintahan Negara Kesatuan Republik Indonesia. Penyelenggara yang di maksud adalah pemerintah Desa, yaitu kepala Desa atau yang di sebut dengan nama lain dan yang di bantu oleh perangkat Desa atau yang di sebut dengan nama lain. Kepastian hukum, tertib penyelenggaraan pemerintahan, tertib kepentingan umum, keterbukaan, proporsionalitas, akuntabilitas, efektifitas dan efisiensi, kearifan lokal, keberagaman dan partisipatif. merupakan bagian dari asas Penyelenggaraan pemerintahan Desa.

Penyelenggaraan pemerintah desa dapat berjalan efektif apabila desa memiliki dana yang memadai. Dalam implementasinya, pembiayaan pemerintah desa kemudian disebut Alokasi Dana Desa (ADD). Pemerintah desa sapat mengupayakan dar berbagi sumber yang sah untuk memenuhi ADD. Menurut Arianto, Y. V., \& Rohman, A. (2018) tujuan dari penggunaan ADD di ialah untuk meningkatkan kesejahteraan masyarakat, pembangunan, membiayai kegiatan pemerintah desa, sebagai tunjangan terhadap kinerja perangkat desa, bantuan tehadap masyarakat yang kurang mampu dan sedang mengalami musibah yang deberikan dalam bentuk Dana Sosial (Dansos), membantu membiayai kegiatan-kegiatan masyarakat desa, berupa pagelaran kesenian. Penggunaan ADD dalam pelaksanaan pembangunan juga sudah diatur dalam pedoman pelaksanaan. Pelaksanaan pembangunan desa juga melibatkan seluruh elemen masyarakat untuk ikut berpartisipasi. Salah satunya saat ini yang menjadi penopang terbesar ADD adalah kucuran dana dari pemerintah pusat yang disebut Dana Desa (DD).

Dana Desa sebagian besar digunakan untuk pembangunan dan penyelenggaraan pemerintahan Desa dengan pemberdayaan masyarakat. Dalam perkembanganya kini desa telah berkembang menjadi berbagai bentuk pemberdayaan sehingga menjadi Desa yang mandiri, maju dan kuat untuk mencapai masyarakat yang adil, makmur dan sejahtera. Desa memiliki wewenang untuk mengatur sendiri kawasanya sesuai dengan kemampuan dan potensi yang di miliki masyarakatnya agar tercapai kesejahteraan dan pemerataan ekonomi.

Dalam menjalankan proses pembangunan desa harus mencerminkan kebersamaan dan gotong royong sebagai wujud pengamalan sila-sila dalam Pancasila demi mewujudkan masyarakat Desa yang adil dan sejahtera. Pelaksanaan pembangunan Desa harus sesuai dengan apa yang di rencanakan dalam proses perencanaan dan masyarakat berhak untuk mengetahui dan melakukan pengawasan terhadap kegiatan pembangunan Desa. Jika implentasi kebijakan pembangunan melalui Dana Desa berjalan dengan baik, maka dapat memberikan kontribusi 
yang signifikan untuk mewujudkan kesejahteraan sosial yang berbasis otonomi Desa. Hal ini salah satunya dengan mengkaji bagaimana implementasi kebijakan pembangunan melalui dana Desa dari berbagai wilayah Desa yang di lakukan penelitian sebelumnya.

\section{Model Implementasi Kebijakan Publik}

Adanya dua pendekatan guna memahami implementasi kebijakan, yaitu: pendekatan top down misalnya dapat disebut sebagai pendekatan yang mendominasi awal perkembangan studi implementasi kebijakan, walaupun dikemudian hari terdapat perbedaaan-perbedaaan sehingga memerlukan pendekatan bottom up, namun pada dasarnya dua pendekatan ini bertitik tolak pada asumsi-asumsi yang sama dalam mengembangkan kerangka analisis tentang studi implementasi. Sesuai dengan apa yang telah di gariskan oleh para pembuat kebijakan maka inti kedua pendekatan ini adalah sejauh mana tindakan para pelaksana (administrator dan birokrat). Menurut George C. Edward dalam Agustino (2012:159) "Implementasi kebijakan publik dalam pendekatan top down dalam menganalisa implementasi kebijakan berfokus pada empat fariabel yang di anggap menentukan proses implementasi kebijakan yaitu: komunikasi, sumberdaya, disposisi, dan struktur birokrasi.

\section{METODE PENELITIAN}

Jenis penelitian ini menggunakan kualitatif, Bodgan dan Taylor dalam Moleong (2014:4), dengan mengambil lokasi penelitian di Desa Waturejo, adapun fokus penelitian Menempatkan fokus pada masalah yang di teliti, Menempatkan fokus berdasarkan domaindomain tertentu organizing domain, Menempatkan fokus yang memiliki nilai temuan untuk mengembangkan iptek, Menempatkan fokus berdasarkan permasalahan yang terkait dengan teori-teori yang telah ada, Sugiyono (2014:209). Pada penelitian ini peneliti memperoleh data dari data primer dan data sekunder dengan teknik pengumpulan data melalui observasi, wawancara dan dokumentasi. Pengambilan sampel pada penelitian ini dilakukan dengan penarikan sampel secara purposife sampling, dan yang menjadi instrumen pada penelitian ini yaitu peneliti sendiri, daftar pertanyaan, camera hand phone, dan alat tulis. Pemeriksaan keabsahan data menggunakan triangulasi teknik, yaitu melalui observasi, wawancara dan dokumentasi, kemudian data yang terkumpul dianalisis dengan menggunakan Menurut Sugiyono (2015:244), yaitu dengan cara reduksi data, penyajian data dan penarikan kesimpulan.

\section{HASIL DAN PEMBAHASAN}

\section{Implementasi Kebijakan Pembangunan Bidang Pemerdayaan Masyarakat Melalui Dana Desa}

Implementasi kebijakan pembangunan Desa merupakan apa yang sesungguhnya di kerjakan oleh pemerintah Desa mengenai kebijakan yang telah di buat terutama mengenai pembangunan Desa itu sendiri. Keluaran kebijakan pembangunan merupakan hal yang kongkrit karena dapat di lihat dan di rasakan oleh masyarakat. Keluaran kebijakan pembangunan di Desa yang di rasakan oleh masyarakat dapat berbentuk suatu yang positif atau pun dapat pula sebaliknya. Sehingga dengan demikian, keluaran kebijakan pembangunan tidak berbicara mengenai baik buruknya dampak yang di lakukan oleh pemerintah, melainkan melihat secara umum. Ada pun sasaran utama dari upaya pembangunan Desa yakni meningkatkan kesejahteraan masyarakat Desa yang berkeadilan, meningkatkan kualitas hidup masyarakat serta penanggulangan kemiskinan melalui pemenuhan kebutuhan dasar masyarakat, pembangunan 
sarana dan prasarana Desa, serta pemanfaatan sumber daya alam dan lingkungan secara berkelanjutan.

Dalam rangka untuk mewujudkan tujuan pembangunan Desa seperti apa yang di amanatkan oleh UU No.6 tahun 2014 di atas maka pemerintah Desa Waturejo mengelurkan berbagai kebijakan pembangunan yang tentunya sesuai dengan hak asal usul serta kondisi Desa Waturejo saat ini. Dan untuk mengetahui bagaimana implementasi kebijakan pembanguna di Desa Waturejo maka peneliti akan mengukur dengan menggunakan 7 (tujuh) standar untuk mengukur sejauh mana proses implementasi kebijakan pembangunan terutama di Desa Waturejo yaitu antara lain: peran pemerintah dalam proses implementasi kebijakan pembangunan bidang pemberdayaan masyarakat, kebijakan pembangunan apa yang menjadi prioritas, bentuk pertanggung jawaban mengenai implementasi kebijakan pembangunan bidang pemberdayaan masyarakat, proses pengawasan yang di lakukan dalam implementai kebijakan pembangunan bidang pemberdayaan masyarakat, sosialisasi dari pemerintah kepada masyarakat mengenai kebijakan pembangunan bidang pemberdayaan yang di keluarkan, tingkat partisipasi masyarakat dalam proses implementasi kebijakan pembangunan di bidang pemberdayaan masyarakat, pengaruh implementasi kebijakan pembangunan bidang pemberdayaan masyarakat terhadap taraf hidup masyarakat, faktor penghambat dan pendukung implementasi kebijakan pembangunan bidang pemberdayaan masyarakat.

\section{Sosialisasi Dari Pemerintah Desa Kepada Masyarakat Tantang Kebijakan Pembangunan Bidang Pemberdayaan Masyarakat Mengenai Pelatihan Perangkat Desa Dan Keterampilan Masyarakat.}

Sosialisasi merupakan suatu proses yang harus di jalankan oleh seorang pemimpin atau fasilitator Desa agar masyarakat menyatu/melebur dan memahami kaca mata peranya dalam pembangunan yaitu memberikan pengawasan serta ikut berpartisipasi. Suksesnya sosialisasi kebijakan pembangunan bidang pemberdayaan masyarakat mengenai pelatihan perangkat Desa dan keterampilan masyarakat apabila proses sosialisasi dapat menjangkau semua wilayah Desa Waturejo sehingga masyarakat memahami, menerima, mendukung kebijakan pembangunan tersebut.

Sosialisasi dari pemerintah Desa kepada masyarakat mengenai kebijakan pembangunan bidang pemberdayaan masyarakat mengenai pelatihan perangkat Desa dan keterampilan masyarakat di Desa Waturejo sudah aktif di laksanakan dalam rangka untuk bisa di ketahui oleh semua masyarakat terkait dengan kebijakan pembangunan bidang pemberdayaan masyarakat mengenai pelatihan perangakat Desa dan keterampilan masyarakat.

\section{Manfaat Dari Kebijakan Pembangunan Bidang Pemberdayaan Masyarakat Mengenai Pelatihan Perangkat Desa Dan Keterampilan Masyarakat.}

Pemerintah Desa Waturejo mengeluarkan kebijakan pembangunan bidang pemberdayaan masyarakat mengenai pelatihan perangkat Desa dan keterampilan masyarakat. Kebijakan ini di keluarkan oleh pemerintah Desa Waturejo sebagai salah satu bentuk program dalam rangka mempercepat terwujudnya kesejahteraan di Desa Waturejo. Dari hasil pengamatan di lapangan manfaat kebijakan pembangunan bidang pemberdayaan masyarakat mengenai pelatihan perangkat Desa dan keterampilan masyarakat belum maksimsal dimana dalam kenyataannya bahwa hanya bisa meningkatkan kualitas pelayanan, namun untuk keterampilan masyarakat belum secara merata berpengaruh terhadap peningkatan ekonomi masyarakat. 
Bentuk Dukungan Aparatur Desa Dalam Implementasi Kebijakan Pembangunan Mengenai Pelatihan Kepala Desa Dan Keterampilan Masyarakat. Dukungan aparatur merupakan salah satu faktor yang sangat penting dalam suatu lembaga pemerintahan disamping faktor lain seperti uang, alat-alat yang berbasis teknologi misalnya komputer dan internet. Dengan demikian maka sumber daya manusia dari para aparatur desa harus dikelola dengan baik untuk meningkatkan efektivitas dan efisiensi organisasi pemerintahan untuk mewujudkan profesional pegawai dalam melakukan pekerjaan. Dukungan aparatur Desa dalam kebijakan pembangunan bidang pemberdayaan masyarakat mengenai pelatihan perangkat Desa dan keterampilan masyarakat sudah aktif di laksanakan yaitu dengan memberikan pelayanan yang prima terhadap masyarakat serta melakukan pendampingan dalam melaksanakan program yang dapat meningkatkan keterampilan masyarakat

\section{Anggaran Yang Di Alokasikan Dalam Implementasi Kebijakan Pembangunan Bidang Pemberdayaan Masyarakat Mengenai Pelatihan Perangkat Desa Dan Keterampilan Masyarakat.}

Dalam menjalankan suatu roda pemerintahan anggaran menjadi salah satu faktor penting dalam mendukung pelaksanaan suatu pekerjaan, sehingga pekerjaan tersebut dalam dilaksanakan dengsan baik sesuai dengan tujuan yang diinginkan bersama. Oleh karena itu, anggaran sangat penting dalam hal menyelaraskan atau mengkoordinasi setiap bagian kegiatan. Sukses dan tidaknya suatu kebijakan pembangunan yang menjadi salah satu faktor yang mempengaruhinya adalah ketersediaan anggaran atau jumlah anggaran yang di alokasikan. Anggaran yang di alokasikan dalam implementasi kebijakan pembangunan bidang pemberdayaan masyarakat mengenai pelatihan perangkat Desa dan keterampilan masyarakat adalah: besaran anggaran untuk pelatihan perangkat Desa sebesar Rp 2.935 .000 dan untuk keterampilan masyarakat sebesar Rp 33.869.000.

\section{Fasilitas Pendukung Dalam Implementasi Kebijakan Pembangunan Bidang Pemberdayaan Masyarakat Mengenai Pelatihan Perangkat Desa Dan Keterampilan Masyarakat.}

Untuk mewujudkan terciptanya implementasi kebijakan yang sesuai dengan apa yang di harapkan sangat di perlukan fasilitas pendukung kebijakan tersebut. Mulai dari hal yang terkecil hingga hal yang besar. Fasilitas pendukung merupakan salah satu indikator yang menetukan keberhasilan suatu kebijakan. Pemerintah Desa Waturejo mempunyai beragam kebijakan pembangunan bidang pemberdayaan masyarakat yang tujuan untuk bisa meningkat kesejahteraan masyarakat itu sendiri lewat berbagai program-program pemberdayaan. Salah satu kebijakan pembangunan yang di keluarkan oleh pemerintah Desa Waturejo di bidang pemberdayaan masyarakat adalah pelatihan perangkat Desa dan keterampilan masyarakat. Kebijakan ini bertujuan untuk meningkatkan kualitas pelayanan kepada masyarakat Desa serta untuk meningkatkan perekonomian masyarakat.

Fasilitas pendukung dalam implementasi kebijakan pembangunan bidang pemberdayaan masyarakat mengenai pelatihan perangkat Desa dan keterampilan masyarakat adalah: 1) untuk pelatihan perangkat Desa meliputi adanya balai Desa dengan luas ruangan yang cukup, komputer Desa yang jumlahnya sesuai dengan jumlah perangkat Desa, ketersediaan kursi dan meja yang sesuai dengan jumlah perangkat Desa dan, 2) untuk keterampilan masyarakat adanya bal;ai RW dan balai RT. 


\section{Faktor Pendukung Dan Penghambat Implementasi Kebijakan Pembangunan Bidang Pemberdayaan Masyarakat Mengenai Pelatihan Perangkat Desa Dan Keterampilan Masyarakat}

Faktor pendukung dan penghambat implementasi kebijakan pembangunan bidang pemberdayaan masyarakat mengenai pelatihan perangkat Desa dan keterampilan masyarakat bahwa:1) faktor pendukungnya meliputi Kerukunan dalam kehidupan sosial, gotong royong yang tinggi, adanya sinergitas yang baik antara pemerintah Desa dengan masyarakat, integritas dari pemerintah Desa dan BPD, sehingga semuanya berjalan dengan prinsip transparansi, serta etos kerja yang tinggi. 2) Sedangkan faktor penghambatnya meliputi rendahnya sumber daya manusia dan masih adanya sikap apatis yang di milki masyarakat, serta jarang ada kondisi komunikasi dan kordinasi yang sempurna antara stake holder di Desa.

\section{KESIMPULAN}

Berdasarkan hasil penelitian dan pembahasan yang telah dilakukan di atas dapat diambil kesimpulan bahwa "implementasi kebijakan pembangunan melalui dana Desa" di Desa Waturejo, kecamatan ngantang, kabupaten malang menunjukkan pada kriteria baik. Hal ini diperlihatkan oleh rata-rata jawaban responden mengenai implementasi kebijakan pembangunan Desa melalui dana Desa Pengaturan mekanisme mengenai implementasi kebijakan pembangunan bidang pemberdayaan melalui dana Desa sudah berjalan dengan baik yaitu mulai dari Sosialisasi dari pemerintah Desa kepada masyarakat, Manfaat dari kebijakan, dukungan aparatur Desa dalam implementasi kebijakan, anggaran yang di alokasikan dalam implementasi kebijakan, serta fasilitas pendukung dalam implementasi kebijakan. Dari hasil implementasi kebijakan pembangunan diatas sudah bisa memaksimalkan pelayanan pemerintah Desa kepada masyarakat, Namun belum terlalu berpengaruh terhadap taraf hidup masyarakat secara berkeadilan. Dalam implementasi kebijakan pembangunan bidang pemberdayaan masyarakat mengenai pelatihan perangkat Desa dam keterampilan masyarakat, di Desa Waturejo, Kecamatan Ngantang kabupaten Malang masih terdapat juga terdapat kendala sebagai bagian dari faktor penghambat yakni: Sumber daya manusia, sikap apatis, serta jarang ada kondisi komunikasi dan kordinasi yang sempurna antara stake holder di Desa.

\section{DAFTAR PUSTAKA}

Agustino, L. (2012). Dasar-dasar kebijakan publik. Bandung: Alfabeta.

Arianto, Y. V., \& Rohman, A. (2018). Efektivitas Penggunaan Alokasi Dana Desa (ADD) Dalam Pelaksanaan Pembangunan Desa. JISIP: Jurnal Ilmu Sosial dan Ilmu Politik, 7(2).

Moleong, L. J. (2014). Metode penelitian kualitatif edisi revisi. Bandung: Remaja Rosdakarya. Peraturan Menteri Dalam Negeri RI No 20 Tahun 2018 Tentang Pengelolaan Keuangan Desa. Sugiyono. (2014). Metode penelitian pendidikan:(pendekatan kuantitatif, kualitatif dan $R \& D)$. Alfabeta. (2015). Metode penelitian pendidikan:(pendekatan kuantitatif, kualitatif dan $R \& D$ ). Alfabeta.

UU No 6 Tahun 2014 Tentang Desa. 